\title{
KETAHANAN LAPANGAN TANAMAN KARET KLON IRR SERI 100 TERHADAP TIGA PATOGEN PENTING PENYAKIT GUGUR DAUN
}

\author{
Field Resistance of IRR 100 Series Rubber Clones to Three Major Pathogens \\ of Leaf Fall Diseases on Rubber Crop
}

\author{
Cici Indriani DALIMUNTHE, Zaida FAIRUZAH dan AIDI-DASLIN \\ Balai Penelitian Sungei Putih, Pusat Penelitian Karet \\ PO.Box 1415, Medan 20001. Sumatera Utara \\ Email : cc_dalimunthe@yahoo.com
}

Diterima : 8 November 2014 / Direvisi : 9 Januari 2015 / Disetujui : 16 April 2015

\begin{abstract}
The main leaf fall diseases on the rubber estate in Indonesia are caused by Colletotrichum gloeosporioides, Oidium heveae and Corynespora cassiicola. Using of resistant clone is an effective and efficient method of control because of the ability to minimize crop damage without using fungicides. The low damage of resistant clone is as a result of an initial population decrease of the pathogen and the rate of pathogen infection. The research was conducted at Sungei Baleh estate PT. Bakrie Sumatera Plantation, Asahan, North Sumatra, using a completely randomized block design with three replications and twelve treatments consisting of IRR 100 series clones (IRR 100, IRR 104, IRR 105, IRR 107, IRR 109, IRR 110, IRR 111, IRR 112, IRR 117, IRR 118, IRR 120) and RRIC 100 as a comparison (control). Observation of attack intensity in the field was done by determining randomly of 10 sample trees/clones and then 10 or 30 leaf petioles of the samples were taken from two opposite sides between planting lines. The purpose of the research was to determine IRR 100 series clone resistance against the three major pathogens leaf fall disease at the different levels of plant ages. The research results showed that attacks intensity of $C$. gloesporioides, $O$. heveae and $C$. cassiicola were significantly different among the IRR 100 series clones. The attacks intensity of C. gloesporioides ranged from 23.55 - 30.99\%, so that all clones tested were categorized as moderate resistance. The attack intensity of $O$. heveae was between 13.98-18.66\%, IRR 100, IRR 104 and IRR 109 were classified resistant while the others were moderate resistant clones. The attacks intensity of $C$. cassiicola ranged from 0.00-74,00\%, IRR 100, IRR 104, IRR 105, IRR 110, IRR 111, IRR 112, IRR 117, IRR 118, $I R R 120$ were classified as resistant clones while IRR 107 was classified as moderately clone and IRR 109 was susceptible clone. All of the tested IRR 100 series clones showed that IRR 100 and IRR
\end{abstract}

104 had good resistance to three pathogens of leaf fall disease with resistance level of clones to $C$. gloesporioides were moderately resistance and to $O$. heveae and C. cassiicola were resistant.

Keywords: Hevea brasilliensis, leaf fall diseases, field resistance, IRR 100 series clones, C. gloeosporioides, O. heveae, C. cassiicola

\section{Abstrak}

Penyakit gugur daun utama pada tanaman karet di Indonesia disebabkan oleh jamur Colletotrichum gloeosporioides, Oidium heveae dan Corynespora cassiicola. Penggunaan klon resisten merupakan metode pengendalian yang efektif dan efisien karena kemampuan tanaman menghambat atau menahan gangguan penyakit tanpa menggunakan fungisida. Rendahnya kerusakan tanaman pada klon resisten adalah sebagai akibat penurunan populasi awal patogen dan laju infeksi patogen. Penelitian dilakukan di kebun Sungei Baleh, PT. Bakrie Sumatera Plantation, Deli Serdang, Sumatera Utara, menggunakan Rancangan Acak Kelompok dengan tiga ulangan dan dua belas perlakuan terdiri dari IRR 100, IRR 104, IRR 105, IRR 107, IRR 109, IRR 110, IRR 111, IRR 112, IRR 117, IRR 118, IRR 120 dan RRIC 100 sebagai pembanding (kontrol). Pengamatan intensitas serangan penyakit gugur daun di lapangan dilakukan dengan menentukan secara acak 10 pohon contoh/klon dan dari setiap pohon diambil 10 tangkai daun atau 30 helai daun dari dua sisi yang berlawanan diantara gawangan tanaman. Tujuan penelitian adalah untuk mengetahui resistensi klon IRR seri 100 terhadap tiga patogen utama penyakit gugur pada berbagai tingkat umur tanaman. Hasil penelitian menunjukkan intensitas serangan C. gloesporioides, O. heveae dan C. cassiicola berbeda nyata diantara klon 
karet IRR seri 100 yang diuji. Intensitas serangan C. gloesporioides berkisar antara 23,55-30,99\% sehingga semua klon yang diuji termasuk dalam kategori agak resisten. Intensitas serangan $O$. heveae antara 13,98-18,66\%, klon IRR 100, IRR 104 dan IRR 109 tergolong resisten sedangkan klon lainnya agak resisten. Intensitas serangan $C$. cassiicola berkisar 0,00-74,00\%, klon IRR 100, IRR 104, IRR 105, IRR 110, IRR 111, IRR 112, IRR 117, IRR 118, IRR 120 tergolong resisten sedangkan IRR 107 moderat dan IRR 109 rentan. Dari seluruh klon IRR seri 100 yang diuji, IRR 100 dan IRR 104 memiliki ketahanan yang baik terhadap ketiga patogen penyebab penyakit gugur daun pada karet dengan tingkat resistensi tergolong agak resisten terhadap C. gloesporioides dan resisten terhadap $O$. Heveae dan $C$. cassiicola.

Kata kunci : Hevea brasilliensis, penyakit gugur daun, ketahanan lapang, klon IRR seri 100, C. gloeosporioides, O. heveae, C. cassiicola

\section{PENDAHULUAN}

Penggunaan klon atau varietas unggul yang resisten merupakan salah satu strategi pengendalian penyakit yang murah dan ramah lingkungan untuk mencegah epidemi dan kerusakan yang ditimbulkan oleh penyakit. Penggunaan pestisida dapat menimbulkan berbagai dampak negatif pada lingkungan seperti menurunnya populasi organisme musuh alami (Supriadi, 2013). Di Indonesia perakitan klon karet unggul baru penghasil lateks tinggi dan tahan penyakit gugur daun, menjadi program utama dalam pemuliaan karet dengan memanfaatkan berbagai sumber genetik berupa kultivar karet tahan penyakit gugur daun sebagai tetua persilangan. Pengembangan klon karet unggul baru ke berbagai wilayah penanaman yang merupakan endemi penyakit gugur daun akan menjadi hambatan jika klon yang ditanam ternyata rentan terhadap gangguan penyakit tersebut. Perkembangan penyakit dikontrol secara genetik. Dasar genetik dari interaksi inang (klon karet) dan patogen merupakan suatu sistem keterkaitan antara respons gen terhadap patogenisitas patogen. Penyakit gugur daun utama yang selalu menyerang tanaman karet disebabkan oleh jamur Colletotrichum gloeosporioides, Oidium heveae dan Corynespora cassiicola. Ketiga penyakit daun tersebut merupakan penyakit penting karena dapat menyerang tanaman sejak di pembibitan, di kebun kayu okulasi (kebun entres), pada tanaman muda maupun tanaman menghasilkan (TM). Pada tanaman menghasilkan, penyakit ini dapat merugikan karena daun-daun muda berguguran, yang mengakibatkan pertumbuhan tanaman terhambat, produksi lateks menurun bahkan mengakibatkan kematian tanaman.

Pada pertanaman karet di lapangan, serangan C. gloeosporioides mengakibatkan gugurnya daun-daun muda sehingga tajuk tanaman tipis, perkembangan lilit batang terhambat dan tertundanya matang sadap (Sujatno et al., 1998). Penyakit C. gloeosporioides menimbulkan epidemi pada tahun 1974 dan 1975 di Jawa, 1976 di Sumatera Utara dan 1989 di Kalimantan Barat dengan mengakibatkan kemerosotan produksi antara $7-45 \%$, tergantung dari intensitas serangan (Pawirosoemardjo dan Suryaningtyas, 2008). Epidemi penyakit timbul karena 1). terjadi penyimpangan pola iklim dari yang normal, yaitu kemarau panjang yang diikuti musim hujan sepanjang tahun, 2). kondisi tanaman karet yang lemah karena kurang perawatan, dan 3). ditanamnya klon-klon yang tergolong rentan, seperti LCB 479, PR 228, PR 225, PR 300, PR 303, PR 305 dan GT 1 (Pawirosoemardjo, 2004).

Penyakit gugur daun $O$. heveae ditemukan di sebagian besar negara-negara penghasil karet tetapi yang paling serius di Sri Lanka, Indonesia, dan Malaysia. Penyakit ini menyerang daun muda yang berumur kurang dari dua minggu. Gejala yang ditunjukkan penyakit Embun tepung Oidium ini adalah membentuk daerah bertepung putih yang tipis di atas permukaan lembaran daun. Serangan berat pada daun yang sangat muda menyebabkan lembaran daun menjadi keriput, layu, mengering, dan gugur. Serangan berulang dapat menyebabkan kemerosotan (penurunan) pada pertumbuhan dan hasil (produksi) (IRRDB, 2006). Kerugian produksi yang disebabkan penyakit ini di beberapa perkebunan, ditaksir mencapai 30 $-40 \%$.

Serangan penyakit daun C. cassiicola mengakibatkan gugurnya daun karet terus menerus sepanjang tahun karena patogen dapat menyerang daun muda maupun tua, 
sehingga tanaman tidak dapat berproduksi dan lambat laun mengalami kematian (Situmorang et al., 1996). Penyakit gugur daun C. cassiicola menyebar mulai tahun 1980 dan menimbulkan epidemi di Indonesia, Sri Langka, Malaysia dan Thailand (Mathew, 2006; Pawirosoemardjo dan Suryaningtyas, 2008). Di Indonesia Penyakit ini ditemukan di Kebun Percobaan Sembawa tahun 1980. Pada tahun 1982 penyakit ditemukan di Kebun Merbuh, Propinsi Jawa Tengah dan pada tahun 1984 di Kebun Cikumpay dan Suka Maju, Propinsi Jawa Barat (Sinulingga et al., 1996). Tahun 1988 dilaporkan beberapa klon karet seperti RRIC 103, KRS 21, dan RRIM 725 terserang berat di Malaysia (Chee, 1988) dan di Thailand serangan patogen mulai terjadi pada tahun 1985 pada klon karet RRIC 103 (Kajornchaiakul, 1987). Hasil survei penyebaran penyakit yang dilakukan pada berbagai sentra perkebunan karet di Sumatera, Jawa dan Kalimantan tahun 1999-2000, memperlihatkan terjadinya kerusakan dengan berbagai tingkat keparahan yang berbeda pada klon RRIM 600, GT1, PR 261 dan BPM 24 (Situmorang et al., 2007a). Hasil penelitian tiga puluh enam isolat menunjukkan adanya virulensi dan efisiensi infeksi yang tinggi pada klon IAN 873, BPM 24 dan GT1 (Situmorang et al., 2007b).

Kegiatan pemuliaan karet yang sudah berjalan selama empat generasi (1910-2010) telah menghasilkan klon-klon unggul generasi-4, di antaranya IRR seri 100 sebagai klon penghasil lateks-kayu. Beberapa klon yaitu IRR 104, IRR 112, IRR 118 telah dilepas dan direkomendasikan dalam penanaman komersial (Woelan et al., 2005 ; Woelan et al., 2006 ; Aidi-Daslin et al., 2009). Ketahanan terhadap penyakit gugur daun sudah dilakukan sejak awal dari mulai seleksi genotipe pada progeni F1 hasil persilangan (Woelan dan Pasaribu, 2007). Kemudian seleksi ketahanan penyakit pada uji lanjutan dilakukan secara laboratorium dan lapangan (Aidi-Daslin, 2013). Aspek ketahanan klon IRR seri 100 terhadap penyakit gugur daun harus mendapat perhatian, karena fakta di lapangan memperlihatkan luasnya epidemi penyakit dan berbagai kasus merosotnya produktivitas karet karena terganggunya perdaunan akibat serangan penyakit gugur daun pada klon-klon produksi tinggi. Diperlukan klon yang spesifik lokasi, khususnya klon resisten penyakit gugur daun untuk pengembangan penanaman karet ke wilayah endemi penyakit maupun beberapa daerah yang sangat berpotensi munculnya gangguan penyakit gugur daun. Penanaman klon-klon produksi tinggi dan tahan penyakit daun pada daerah tersebut, akan menjamin produktivitas yang stabil selama siklus ekonomi karet yang lamanya kurang lebih 25 tahun. Dalam artikel ini disampaikan hasil penelitian uji lapangan ketahanan berbagai klon karet IRR seri 100 terhadap patogen penyakit gugur daun Colletotrichum gloeosporioides, Oidium heveae dan Corynespora cassiicola.

\section{BAHAN DAN METODE}

Penelitian ini dilaksanakan dari tahun 2002 sampai dengan 2012 di kebun Sungei Baleh, PT. Bakrie Sumatera Plantation, Kabupaten Asahan, Sumatera Utara dengan ketinggian tempat $15 \mathrm{~m}$ dpl (di atas permukaan laut). Rata-rata curah hujan berkisar $1.400-1.800 \mathrm{~mm} / \mathrm{th}$, suhu berkisar $27-33^{\circ} \mathrm{C}$ dan hari hujan berkisar 77 110 hari/th. Penelitian ini menggunakan Rancangan Acak Kelompok, tiga ulangan, perlakuan klon terdiri dari IRR 100, IRR 104, IRR 105, IRR 107, IRR 109, IRR 110, IRR 111, IRR 112, IRR 117, IRR 118, IRR 120 dan RRIC 100 sebagai pembanding. Pengamatan intensitas serangan penyakit gugur daun di lapangan dilakukan dengan menentukan secara acak 10 pohon contoh/klon. Dari setiap pohon diambil 10 tangkai daun atau 30 helai daun dari dua sisi yang berlawanan di antara gawangan tanaman.

Intensitas serangan penyakit dihitung menurut metode yang dikembangkan oleh Pawirosoemardjo (1999) didasarkan pada nilai bercak dan cacat daun dengan skor $0-6$ untuk penyakit $C$. gloeosporioides (Tabel 1). Sementara untuk penyakit $O$. Heveae dan C. cassiicola penilaian bercak serangan tertera pada Tabel 2 dan 3. 
Tabel 1. Nilai bercak dan cacat daun serangan penyakit gugur daun C. gloeosporioides Table 1. Spots and damage value of C. gloeosporioides leaffall disease attack

\begin{tabular}{cl}
\hline $\begin{array}{c}\text { Skor } \\
\text { Score }\end{array}$ & \multicolumn{1}{c}{$\begin{array}{c}\text { Keterangan } \\
\text { Remark }\end{array}$} \\
\hline 0 & $\begin{array}{l}\text { Tidak terdapat bercak atau cacat pada daun } \\
\text { There is no spot or leaf damage } \\
\text { Terdapat bercak atau cacat pada daun } 1 / 16 \text { bagian } \\
\text { There is spot or damage on } 1 / 16 \text { part of leaf } \\
\text { Terdapat bercak atau cacat pada daun } 1 / 8 \text { bagian } \\
\text { There is spot or damage on } 1 / 8 \text { part of leaf } \\
\text { Terdapat bercak atau cacat pada daun } 1 / 4 \text { bagian } \\
\text { There is spot or damage on } 1 / 4 \text { part of leaf } \\
\text { Terdapat bercak atau cacat pada daun } 1 / 2 \text { bagian } \\
\text { There is spot or damage on } 1 / 2 \text { part of leaf } \\
\text { Terdapat bercak atau cacat pada daun }>1 / 2 \text { bagian } \\
\text { There is spot or damage on }>1 / 2 \text { part of leaf } \\
\text { Daun gugur total } \\
\text { Total leaf fall }\end{array}$ \\
\hline
\end{tabular}

Tabel 2. Nilai bercak serangan penyakit gugur daun $O$. heveae

Table 2. Spots value of $\mathrm{O}$. heveae leaf fall disease

\begin{tabular}{cl}
$\begin{array}{c}\text { Skor } \\
\text { Score }\end{array}$ & \multicolumn{1}{c}{$\begin{array}{c}\text { Keterangan } \\
\text { Remarks }\end{array}$} \\
\hline 0 & $\begin{array}{l}\text { Tidak terdapat bercak pada daun } \\
\text { There is no spot on leaf } \\
\text { Terdapat bercak } 1 / 16 \text { bagian pada daun } \\
\text { There is spot on 1/16 }\end{array}$ \\
2 & $\begin{array}{l}\text { Terdapat bercak 1/8 bagian pada daun } \\
\text { There is spot on 1/8 part of leaf }\end{array}$ \\
3 & $\begin{array}{l}\text { Terdapat bercak 1/4 bagian pada daun } \\
\text { There is spot on 1/4 part of leaf }\end{array}$ \\
4 & $\begin{array}{l}\text { Terdapat bercak 1/2 bagian pada daun } \\
\text { There is spot on 1/2 part of leaf }\end{array}$ \\
5 & $\begin{array}{l}\text { There is spot on }>1 / 2 \text { bagian } \\
\text { Terdapat bercak pada seluruh permukaan daun } \\
\text { There is spot on all leaf surface }\end{array}$ \\
\hline
\end{tabular}

Tabel 3. Nilai bercak serangan penyakit gugur daun C. cassiicola

Table 3. Spots value of C. cassiicola leaffall disease attack

\begin{tabular}{cl}
$\begin{array}{c}\text { Skor } \\
\text { Score }\end{array}$ & \multicolumn{1}{c}{$\begin{array}{c}\text { Keterangan } \\
\text { Remarks }\end{array}$} \\
\hline 0 & $\begin{array}{l}\text { Tidak terdapat bercak pada urat/tulang daun } \\
\text { There is spot on leaf rib } \\
\text { Terdapat 1-3 bercak pada urat daun } \\
\text { There are 1-3 spots on leaf rib } \\
\text { Terdapat beberapa bercak menyatu } \otimes 1 / 4 \text { bagian daun }\end{array}$ \\
2 & $\begin{array}{l}\text { There is continuous spot on } \otimes 1 / 4 \text { part of leaf } \\
\text { Terdapat bercak pada tulang / urat daun menyebabkan } \otimes 1 / 2 \\
\text { daun menguning }\end{array}$ \\
& $\begin{array}{l}\text { There is spot on leaf rib causing yellowing on } \otimes 1 / 2 \text { part of leaf } \\
\text { Terdapat bercak pada tulang / urat daun menyebabkan }>1 / 2 \\
\text { daun menguning }\end{array}$ \\
& $\begin{array}{l}\text { There is spot on leaf rib causing yellowing on }>1 / 2 \text { part of leaf } \\
\text { Daun gugur total }\end{array}$ \\
\hline
\end{tabular}


Intensitas serangan penyakit gugur daun dihitung berdasarkan rumus yang dikembangkan Pawirosoemardjo (1999) sebagai berikut:

$$
I=\frac{\sum(n \times v)}{Z \times N} \times 100 \%
$$

I : intensitas serangan

$\mathrm{n}$ : jumlah daun dari setiap kategori serangan

$\mathrm{v}$ : nilai skala dari setiap kategori serangan

Z : nilai skala tertinggi dari kategori serangan

$\mathrm{N}$ : jumlah daun yang diamati

Penilaian kualitatif ketahanan klon terhadap serangan penyakit gugur daun ditentukan berdasarkan nilai intensitas serangan, dengan kriteria sebagai berikut berdasarkan Pawirosoemardjo (1999) :

$\begin{array}{ll}\text { Resisten } & : 0-20 \% \\ \text { Agak resisten } & : 21-40 \% \\ \text { Moderat } & : 41-60 \% \\ \text { Agak rentan } & : 61-80 \% \\ \text { Rentan } & : 81-100 \%\end{array}$

\section{HASIL DAN PEMBAHASAN}

\section{Intensitas Serangan Penyakit}

Hasil pengamatan rataan intensitas serangan patogen penyakit gugur daun Colletotrichum gloeosporioides terhadap klon karet IRR seri 100 yang diuji menunjukkan perbedaan yang signifikan diantara klon, berkisar antara 23,5530,99\% (Tabel 4). Rataan intensitas serangan pada klon IRR 100 (25,53\%), IRR 107 (24,43\%), IRR 109 (25,09\%), IRR 111 (23,55\%), IRR 112 (26,88\%) dan IRR 117 $(25,88 \%)$ tidak berbeda nyata dengan RRIC $100(23,44 \%)$ sebagai klon pembanding. Klon IRR 104, IRR 105, IRR 110, IRR 118 dan IRR 120 memiliki intensitas serangan lebih besar $(28,54-30,99 \%)$ dan berbeda nyata dengan klon RRIC 100. Intensitas serangan terendah terdapat pada klon IRR 111 (23,44\%) dan tertinggi pada klon IRR 105 $(30,99 \%)$.

Serangan penyakit gugur daun $C$. gloeosporioides pada umur tanaman 3, 6 dan 9 tahun di lapangan menunjukkan tingkat yang bervariasi. Pada masa tanaman belum menghasilkan (TBM) umur 3 tahun, klon IRR 111 terserang paling rendah $(18,64 \%)$ dan

Tabel 4. Intensitas serangan C. gloeosporioides pada klon karet IRR seri 100 Table 4. Attack intensity of C. gloeosporioides on IRR 100 series rubber clones

\begin{tabular}{ccccc}
\hline \multirow{2}{*}{ Klon } & \multicolumn{3}{c}{ Intensitas serangan (\%), umur } & \multirow{2}{*}{$\begin{array}{c}\text { Rataan } \\
\text { Average }\end{array}$} \\
\cline { 2 - 4 } Clones & 3 tahun & 6 tahun & 9 tahun & \\
& 3 years & 6 years & 9 years & \\
\hline IRR 100 & $33,58 \mathrm{c}$ & $21,33 \mathrm{~b}$ & $21,67 \mathrm{a}$ & $25,53 \mathrm{a}$ \\
IRR 104 & $33,62 \mathrm{c}$ & $30,37 \mathrm{e}$ & $23,33 \mathrm{a}$ & $29,11 \mathrm{~b}$ \\
IRR 105 & $34,30 \mathrm{c}$ & $25,33 \mathrm{c}$ & $33,33 \mathrm{~d}$ & $30,99 \mathrm{~b}$ \\
IRR 107 & $31,96 \mathrm{c}$ & $19,67 \mathrm{~b}$ & $21,67 \mathrm{a}$ & $24,43 \mathrm{a}$ \\
IRR 109 & $34,62 \mathrm{c}$ & $17,33 \mathrm{a}$ & $23,33 \mathrm{a}$ & $25,09 \mathrm{a}$ \\
IRR 110 & $36,96 \mathrm{~d}$ & $22,67 \mathrm{c}$ & $30,00 \mathrm{c}$ & $29,88 \mathrm{~b}$ \\
IRR 111 & $18,64 \mathrm{a}$ & $27,00 \mathrm{~d}$ & $25,00 \mathrm{~b}$ & $23,55 \mathrm{a}$ \\
IRR 112 & $31,30 \mathrm{c}$ & $22,67 \mathrm{c}$ & $26,67 \mathrm{~b}$ & $26,88 \mathrm{a}$ \\
IRR 117 & $35,30 \mathrm{~d}$ & $20,67 \mathrm{~b}$ & $21,67 \mathrm{a}$ & $25,88 \mathrm{a}$ \\
IRR 118 & $30,96 \mathrm{c}$ & $24,67 \mathrm{c}$ & $30,00 \mathrm{c}$ & $28,54 \mathrm{~b}$ \\
IRR 120 & $38,64 \mathrm{~d}$ & $26,07 \mathrm{~d}$ & $26,67 \mathrm{~b}$ & $30,46 \mathrm{~b}$ \\
RRIC 100 & $21,98 \mathrm{~b}$ & $20,00 \mathrm{~b}$ & $28,33 \mathrm{c}$ & $23,44 \mathrm{a}$ \\
\hline
\end{tabular}

Angka yang diikuti oleh huruf yang sama pada kolom yang sama, tidak berbeda nyata pada taraf uji 0,05 Figures followed by the same letter in the same column are not significantly different at 0,05 
setelah disadap pada umur 9 tahun, semua klon IRR seri 100 terserang lebih merata dengan rata-rata intensitas serangan $>20 \%$. Berdasarkan pendapat Basuki dan Suwarto (1991), serangan C. gloeosporioides pada masa tanaman belum menghasilkan (TBM) karet dapat mengakibatkan tertundanya matang sadap 0,5-3 tahun dan pada tanaman menghasilkan (TM) mengakibatkan penurunan produksi sampai $40 \%$ tergantung intensitas serangan penyakit. Epidemi penyakit gugur daun $C$. gloeosporioides sudah cukup luas di perkebunan karet Indonesia, sehingga di lapangan semua klon yang ditanam dalam skala komersial umumnya mendapat serangan dengan variabilitas yang berbeda. Pada Gambar 1 dapat dilihat bahwa klon IRR seri 100 yang diuji masih berada dalam kisaran ketahanan agak resisten s.d resisten pada umur tanaman 3, 6, dan 9 tahun di lapangan dengan kisaran intensitas serangan $17,33-38,64 \%$.

Rataan serangan penyakit Oidium heveae berkisar 13,98-18,66\% (Tabel 5). Rataan intensitas serangan pada klon IRR 104 (13,98\%) paling rendah dan berbeda nyata dengan klon pembanding RRIC 100 $(17,10 \%)$, sedangkan pada klon IRR 100
(15,65\%), IRR 111 (15,98\%) dan IRR 112 $(15,59 \%)$ menunjukkan perbedaan yang tidak nyata dengan RRIC 100 . Serangan tertinggi terdapat pada klon IRR 105, IRR 107, IRR 109, IRR 110, IRR 117, IRR 118, IRR $120(17,65-18,66 \%)$ dan berbeda nyata dengan RRIC 100. Klon IRR seri 100 yang diuji termasuk dalam tingkat kategori resisten terhadap penyakit gugur daun $O$. heveae dengan rata-rata intensitas serangan $<20 \%$. Serangan terjadi pada musim kering di mana masih terdapat hujan kecil dan kelembaban udara cukup tinggi. Cuaca berkabut dan suhu tinggi mendorong perkembangan penyakit $O$. heveae. Fakta di lapangan menunjukkan hampir semua klon IRR seri 100 yang diamati terkena infeksi dengan nilai serangan yang masih dapat ditoleransi. Pada Gambar 2 dapat dilihat bahwa semua klon IRR seri 100 yang diuji mengalami serangan $O$. heveae tertinggi pada umur sembilan tahun.

Rataan intensitas serangan penyakit gugur daun Corynespora cassicola pada klon IRR seri 100 menunjukkan perbedaan yang nyata diantara klon yang diuji, berkisar 0,00-74,00\% (Tabel 6). Intensitas serangan patogen C. cassiicola terendah $(0,00 \%)$ terdapat pada klon IRR 111, IRR 117, IRR

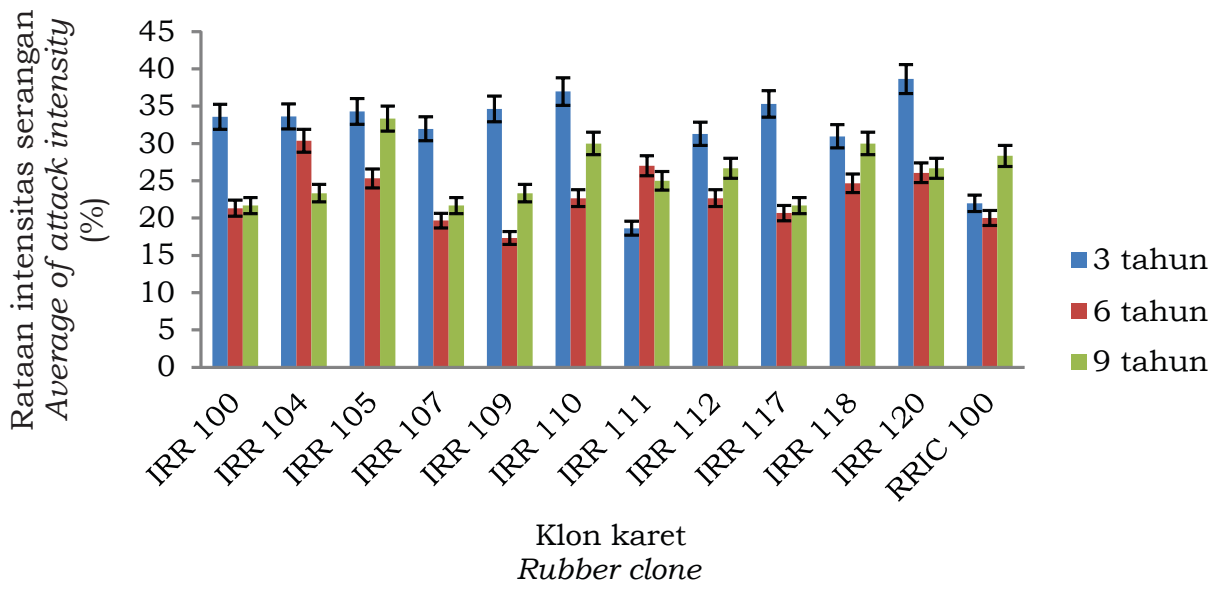

Gambar 1. Intensitas serangan C.gloeosporioides pada berbagai klon dengan umur 3, 6, dan 9 tahun Figure 1. Attack intensity of C. gloeosporioides on various clones at the age of 3, 6, and 9 years 
Tabel 5. Intensitas serangan $O$. heveae pada klon karet IRR seri 100 Table 5. Attack intensity of $\mathrm{O}$. heveae on IRR 100 series rubber clones

\begin{tabular}{ccccc}
\hline \multirow{2}{*}{ Klon } & \multicolumn{3}{c}{ Intensitas serangan (\%), umur } & \multirow{2}{*}{$\begin{array}{c}\text { Rataan } \\
\text { Average }\end{array}$} \\
\cline { 2 - 4 } Clones & 3 tahun & 6 tahun & 9 tahun & \\
& 3 years & 6 years & 9 years & \\
\hline IRR 100 & $14,96 \mathrm{~b}$ & $12,00 \mathrm{c}$ & $20,00 \mathrm{~b}$ & $15,65 \mathrm{~b}$ \\
IRR 104 & $17,28 \mathrm{c}$ & $8,00 \mathrm{~b}$ & $16,67 \mathrm{a}$ & $13,98 \mathrm{a}$ \\
IRR 105 & $11,96 \mathrm{a}$ & $16,00 \mathrm{e}$ & $25,00 \mathrm{c}$ & $17,65 \mathrm{c}$ \\
IRR 107 & $17,30 \mathrm{c}$ & $13,67 \mathrm{~d}$ & $23,33 \mathrm{c}$ & $18,10 \mathrm{c}$ \\
IRR 109 & $17,30 \mathrm{c}$ & $20,00 \mathrm{f}$ & $16,67 \mathrm{a}$ & $17,99 \mathrm{c}$ \\
IRR 110 & $13,28 \mathrm{a}$ & $16,00 \mathrm{e}$ & $26,67 \mathrm{~d}$ & $18,65 \mathrm{c}$ \\
IRR 111 & $18,62 \mathrm{c}$ & $6,00 \mathrm{a}$ & $23,33 \mathrm{c}$ & $15,98 \mathrm{~b}$ \\
IRR 112 & $12,10 \mathrm{a}$ & $11,34 \mathrm{c}$ & $23,33 \mathrm{c}$ & $15,59 \mathrm{~b}$ \\
IRR 117 & $19,98 \mathrm{~d}$ & $13,00 \mathrm{~d}$ & $21,67 \mathrm{~b}$ & $18,22 \mathrm{c}$ \\
IRR 118 & $18,30 \mathrm{c}$ & $12,67 \mathrm{c}$ & $25,00 \mathrm{c}$ & $18,66 \mathrm{c}$ \\
IRR 120 & $13,62 \mathrm{~b}$ & $14,00 \mathrm{~d}$ & $26,67 \mathrm{~d}$ & $18,10 \mathrm{c}$ \\
RRIC 100 & $14,30 \mathrm{~b}$ & $13,67 \mathrm{~d}$ & $23,33 \mathrm{c}$ & $17,10 \mathrm{~b}$ \\
\hline
\end{tabular}

Angka yang diikuti oleh huruf yang sama pada kolom yang sama, tidak berbeda nyata pada taraf uji 0,05

Figures followed by the same letter in the same column are not significantly different at 0,05

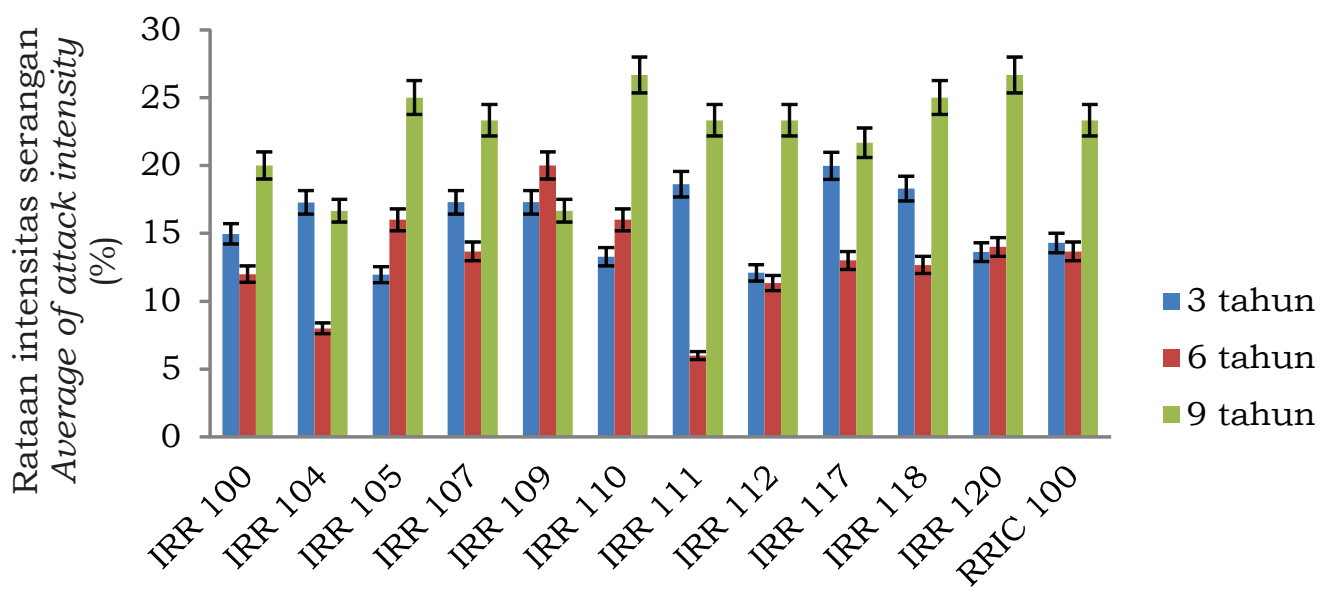

Klon karet Rubber clone

Gambar 2. Intensitas serangan $O$. heveae pada berbagai klon dengan umur 3, 6, dan 9 tahun

Figure 2. Attack intensity of $\mathrm{O}$. heveae on various clones at the age of 3, 6, and 9 years.

118 dan IRR 120 yang tidak berbeda nyata dengan klon RRIC 100 (0,00\%). Klon yang mendapat serangan tertinggi adalah IRR 107 (32,67\%) dan IRR 109 (74,00\%), sedangkan klon lainnya IRR 100, IRR 104, IRR 105, IRR 110 dan IRR 112 berada pada kisaran 0,67$3,47 \%$
Berdasarkan hasil pengamatan intensitas serangan penyakit C. cassiicola di lapangan pada umur 3, 6, dan 9 tahun, tingkat resistensi klon IRR seri 100 memiliki rentang yang luas, sehingga terdapat kelompok klon resisten, moderat dan rentan. Hasil penelitian Munir et al (2012) 
menyebutkan bahwa dari hasil uji tujuh isolat Corynespora yang berasal dari berbagai sentra perkebunan karet terhadap beberapa klon memperlihatkan tingkat resistensi yang tergolong moderat sampai resisten. Pada Gambar 3 menunjukkan intensitas serangan tertinggi adalah pada masa tanaman menghasilkan umur 6 dan 9 tahun yang terdapat pada klon IRR 107 (28,00-54,00\%) dan IRR 109 (82,00$86,00 \%)$. Setelah buka sadap, klon yang rentan memiliki daya tahan yang lemah sehingga lebih mudah terserang patogen $C$. Cassiicola. Ketahanan terhadap penyakit gugur daun sangat tergantung kepada sifat genetik yang dimiliki oleh klon (Aidi-Daslin et al., 2011). Adanya intensitas serangan yang tinggi pada klon IRR 109 mengindikasikan bahwa secara genetik IRR 109 memang rentan terhadap penyakit gugur daun $C$. cassiicola (Tabel 6).

Menurut Nurhaimi (2006), mekanisme resistensi daun karet terhadap
C. cassiicola adalah berkaitan dengan kemampuan tanaman untuk mengatasi penyebaran toksin. Perbedaan nyata antara respons klon resisten dan rentan terlihat pada invasi patogen dalam jaringan tanaman. Serangan pada klon rentan menyebabkan kerusakan pada sel epidermis, nukleus dan organel lainnya, sehingga akhirnya menimbulkan kerusakan parah pada daun. Pada klon resisten, kolonisasi jamur terbatas hanya pada beberapa sel di sekitar hifa. Kondisi tersebut menimbulkan dugaan bahwa klon resistensi memiliki suatu molekul yang disandikan oleh suatu gen tertentu, sehingga mampu mengenal atau langsung mengatasi perkembangan patogen.

\section{Penilaian Resistensi Klon}

Hasil pengamatan ketahanan lapangan (Tabel 7) menunjukkan adanya perbedaan resistensi klon karet IRR seri 100 yang diuji terhadap tiga patogen penyebab

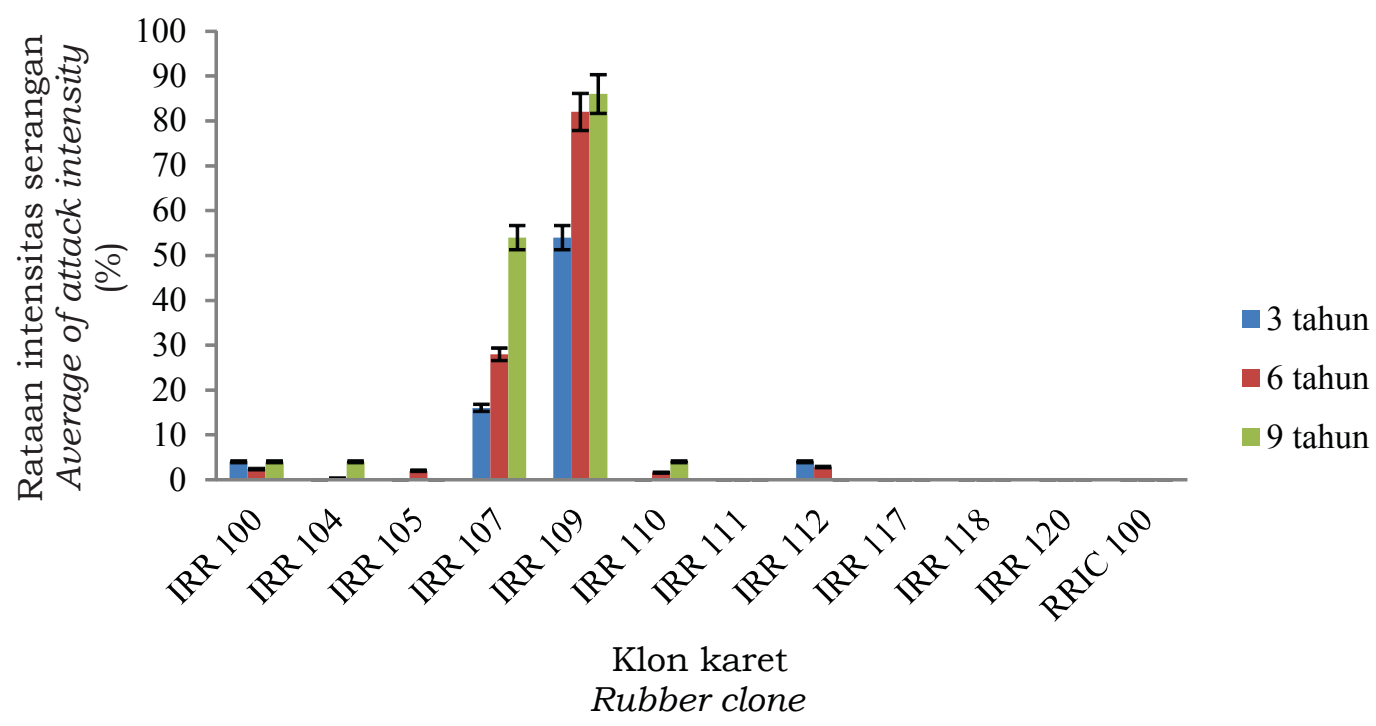

Gambar 3. Intensitas serangan $C$. cassiicola pada berbagai klon dengan umur 3, 6, dan 9 tahun

Figure 3. Attack intensity of C. cassiicola on various clones at the age of 3, 6, and 9 years. 
Tabel 6. Intensitas serangan C. cassiicola pada klon karet IRR seri 100 Table 6. Attack intensity of C. cassiicola on IRR 100 series rubber clones

\begin{tabular}{ccccc}
\hline \multirow{2}{*}{ Klon } & \multicolumn{3}{c}{$\begin{array}{c}\text { Intensitas serangan (\%), umur } \\
\text { Attack intensity (\%), ages }\end{array}$} & Rataan \\
Clones & 3 tahun & 6 tahun & 9 tahun & Average \\
& 3 years & 6 years & 9 years & $3,47 \mathrm{e}$ \\
IRR 100 & $4,00 \mathrm{~b}$ & $2,40 \mathrm{e}$ & $4,00 \mathrm{~b}$ & $1,47 \mathrm{c}$ \\
IRR 104 & $0,00 \mathrm{a}$ & $0,40 \mathrm{~b}$ & $4,00 \mathrm{~b}$ & $0,67 \mathrm{~b}$ \\
IRR 105 & $0,00 \mathrm{a}$ & $2,00 \mathrm{~d}$ & $0,00 \mathrm{a}$ & $32,67 \mathrm{f}$ \\
IRR 107 & $16,00 \mathrm{c}$ & $28,00 \mathrm{f}$ & $54,00 \mathrm{c}$ & $74,00 \mathrm{~g}$ \\
IRR 109 & $54,00 \mathrm{~d}$ & $82,00 \mathrm{~g}$ & $86,00 \mathrm{~d}$ & $1,87 \mathrm{c}$ \\
IRR 110 & $0,00 \mathrm{a}$ & $1,60 \mathrm{c}$ & $4,00 \mathrm{~b}$ & $0,00 \mathrm{a}$ \\
IRR 111 & $0,00 \mathrm{a}$ & $0,00 \mathrm{a}$ & $0,00 \mathrm{a}$ & $2,27 \mathrm{~d}$ \\
IRR 112 & $4,00 \mathrm{~b}$ & $2,80 \mathrm{e}$ & $0,00 \mathrm{a}$ & $0,00 \mathrm{a}$ \\
IRR 117 & $0,00 \mathrm{a}$ & $0,00 \mathrm{a}$ & $0,00 \mathrm{a}$ & $0,00 \mathrm{a}$ \\
IRR 118 & $0,00 \mathrm{a}$ & $0,00 \mathrm{a}$ & $0,00 \mathrm{a}$ & $0,00 \mathrm{a}$ \\
IRR 120 & $0,00 \mathrm{a}$ & $0,00 \mathrm{a}$ & $0,00 \mathrm{a}$ & $0,00 \mathrm{a}$ \\
RRIC 100 & $0,00 \mathrm{a}$ & $0,00 \mathrm{a}$ & $0,00 \mathrm{a}$ & 0.05
\end{tabular}

Angka yang diikuti oleh huruf yang sama pada kolom yang sama, tidak berbeda nyata pada taraf uji 0,05 Figures followed by the same letter in the same column are not significantly different at 0,05

Tabel 7. Resistensi klon karet IRR seri 100 umur 9 tahun terhadap tiga patogen penyakit gugur daun

Table 7. Resistance of IRR 100 series rubber clones over 9 years to three of leaf fall diseases pathogens

\begin{tabular}{cccc}
\hline \multirow{2}{*}{ Klon } & \multicolumn{3}{c}{$\begin{array}{c}\text { Nilai resistensi } \\
\text { Rate of resistances }\end{array}$} \\
\cline { 2 - 4 } & C. gloeosporioides & O. heveae & C. cassiicola \\
\hline IRR 100 & MR & $\mathrm{R}$ & $\mathrm{R}$ \\
IRR 104 & $\mathrm{MR}$ & $\mathrm{R}$ & $\mathrm{R}$ \\
IRR 105 & $\mathrm{MR}$ & $\mathrm{MR}$ & $\mathrm{R}$ \\
IRR 107 & $\mathrm{MR}$ & $\mathrm{MR}$ & $\mathrm{M}$ \\
IRR 109 & $\mathrm{MR}$ & $\mathrm{R}$ & $\mathrm{S}$ \\
IRR 110 & $\mathrm{MR}$ & $\mathrm{MR}$ & $\mathrm{R}$ \\
IRR 111 & $\mathrm{MR}$ & $\mathrm{MR}$ & $\mathrm{R}$ \\
IRR 112 & $\mathrm{MR}$ & $\mathrm{MR}$ & $\mathrm{R}$ \\
IRR 117 & $\mathrm{MR}$ & $\mathrm{MR}$ & $\mathrm{R}$ \\
IRR 118 & $\mathrm{MR}$ & $\mathrm{MR}$ & $\mathrm{R}$ \\
IRR 120 & $\mathrm{MR}$ & $\mathrm{MR}$ & $\mathrm{R}$ \\
RRIC 100 & $\mathrm{MR}$ & $\mathrm{MR}$ & $\mathrm{R}$ \\
\hline
\end{tabular}

Keterangan (notes).

$\mathrm{R} \quad$ : resisten (resistant)

$\mathrm{MR}$ : agak resisten (moderately resistant)

MS : agak rentan (moderately susceptible)

$\mathrm{M}$ : moderat (moderate) 
gugur daun C. gloeosporioides, O.heveae dan C. cassiicola. Semua klon IRR seri 100 yang diuji masuk dalam kelompok agak resisten terhadap penyakit gugur daun $C$. gloeosporioides. Klon IRR 100, IRR 104 dan IRR 109 termasuk dalam kelompok kategori klon yang resisten terhadap $O$. heveae sedangkan klon IRR seri 100 lainnya tergolong agak resisten. Klon yang tergolong resisten terhadap C. cassiicola adalah IRR 100, IRR 104, IRR 105, IRR 110, IRR 111, IRR 112, IRR 117, IRR 118, IRR 120, sedangkan IRR 107 tergolong moderat dan IRR 109 tergolong rentan.

Sebagian besar klon IRR seri 100 yang diuji termasuk dalam kategori agak resisten terhadap dua patogen penyakit gugur daun $C$. gloesoporioides, dan $O$. heveae dan resisten terhadap C. cassiicola yaitu IRR 105, IRR 110, IRR 111, IRR 112, IRR 117, IRR 118 dan IRR 120. Sementara klon IRR 100 dan IRR 104 memiliki ketahanan yang lebih baik terhadap ketiga patogen penyebab penyakit gugur daun pada karet, dengan tingkat ketahanan tergolong agak resisten terhadap $C$. gloesporioides dan resisten terhadap $O$. Heveae dan C. cassiicola.

\section{KESIMPULAN}

Semua klon karet IRR seri 100 yang diuji termasuk dalam kategori agak resisten terhadap penyakit gugur daun $C$. gloesporioides. Klon yang resisten terhadap penyakit $O$. heveae adalah IRR 100, IRR 104 dan IRR 109 sedangkan klon lainnya tergolong agak resisten. Klon IRR 100, IRR 104, IRR 105, IRR 110, IRR 111, IRR 112, IRR 117, IRR 118, IRR 120 tergolong resisten terhadap penyakit gugur daun $C$. cassiicola sedangkan IRR 107 tergolong moderat dan IRR 109 tergolong rentan. Klon IRR 100 dan IRR 104 memiliki ketahanan yang baik terhadap ketiga patogen penyebab penyakit gugur daun pada karet dengan tingkat resistensi tergolong agak resisten terhadap C. gloesporioides dan resisten terhadap $O$. Heveae dan C. cassiicola. Dalam penelitian selanjutnya mekanisme resistensi yang tepat perlu diteliti lebih lanjut.

\section{DAFTAR PUSTAKA}

Aidi-Daslin, S. Woelan, M. Lasminingsih, dan H. Hadi. 2009. Kemajuan Pemuliaan dan Seleksi Tanaman Karet di Indonesia. Pros. Lok. Nas. Pemuliaan Tanaman Karet. Batam, 46 Agustus. Pusat Penelitian Karet.: 5059.

Aidi-Daslin, Z. Fairuzah dan C.I. Dalimunthe. 2011. Uji Resistensi Genotipe Terpilih Dari Plasma Nutfah IRRDB terhadap Penyakit Gugur Daun Corynespora Dengan Metode Cakram Daun. Jurnal Penelitian Karet 29(1) : 16-24.

Aidi-Daslin. 2013. Ketahanan Genetik Berbagai Klon Karet Introduksi Terhadap Penyakit Gugur Daun. Jurnal Penelitian Karet 31(2) : 79-87.

Basuki dan Suwarto. 1991. Penanggulangan Penyakit Gugur Daun Pada Tanaman Karet. Pertemuan Teknis Karet Perkebunan Besar Swasta Nasional Provinsi Sumatera Utara. Pusat Penelitian Karet, Medan.

Chee, K.H. 1988. Corynespora Leaf Spot Malaysia. Country report Malaysia, Thailand, Sri Lanka and Indonesia. Workshop on Leaf Spot Disease on Hevea Rubber. Bogor, Februari 12-13. Pusat Penelitian Karet.: 5

IRRDB. 2006. Portrait of the Global Rubber Industry. IRRDB. Kuala Lumpur, Malaysia.

Kajornchaiakul, P. 1987. Corynespora Disease of Hevea in Thailand. Proc. IRRDB. Symp. Pathol. of Hevea brasiliensis. Chiang May, November 23. IRRDB.: 1- 5 .

Mathew, J. 2006. Clonal Resistance of Hevea brasiliensis to Corynespora Leaf Fall Disease. Corynespora Leaf Fall Disease Of Hevea Brasiliensis Strategiest For Management. Rubber Research Institute of India. Kottayam, India. 
Munir, M., H. Suryaningtyas dan Kuswanhadi. 2012 . Analisis Keragaman Genetik Isolat Corynespora Cassiicola (Berk \& Curt) WEI. Di Indonesia Menggunakan Marker ISSR (Inter Simple Sequence Repeat). Jurnal Penelitian Karet 30(2) : 86-99.

Nurhaimi. 2006. Ekspresi Gen-Gen Responsif Tanaman Corynespora Cassiicola Pada Tanaman Karet (Hevea brasiliensis, Muell. Arg.). Disertasi. Sekolah Pascasarjana Institut P e rtanian Bogor. w w w. Repository.ipb.ac.id., Diakses tanggal 04 Mei 2012.

Pawirosoemardjo, S. 1999. Epidemiologi dan Pengendalian Penyakit Gugur Daun Corynespora dan Colletotrichum Secara Terpadu. Laporan Proyek Penelitian. Pusat Penelitian Karet, Sungei Putih.

Pawirosoemardjo, S. 2004. Managemen Pengendalian Penyakit Penting Dalam Upaya Mengamankan Target Produksi Karet Nasional Tahun 2020. Pertemuan Teknis Strategi Pengelolaan Penyakit Tanaman Karet untuk Mempertahankan Potensi Produksi Mendukung Industri Perkaretan Indonesia Tahun 2020. Palembang, 67 Oktober. Balai Penelitian Sembawa.: 17 .

Pawirosoemardjo, S dan H. Suryaningtyas. 2008. Strategi Pengendalian Penyakit Gugur Daun dan Pencegahan Penyakit Hawar Daun Amerika Selatan Pada Tanaman Karet di Indonesia. Pros. Lokakarya Nasional Agribisnis Karet 2008. Yogyakarta, 20-21 Agustus. Pusat Penelitian Karet.: 194-212.

Sinulingga, W., Suwarto dan H. Soepena. 1996. Current Status of Corynespora Leaf Fall in Indonesia. Proc. CLF Disease of Hevea Rubber. Medan, 1617 Desember. Pusat Penelitian Karet.: 29-36.
Situmorang, A., A. Budiman, S. Pawirosoemardjo dan M . Lasminingsih. 1996. Epidemic of Corynespora Leaf Fall Disease and its Preventive Methods in rubber plantation. Proc. CLF Disease of Hevea Rubber. Medan, 16-17 Desember. Pusat Penelitian Karet.: 111-132.

Situmorang, A., M. S. Sinaga, R. Suseno, S.H. Hidayat, Siswanto dan A. Darussamin. 2007a. Sebaran Penyakit Gugur Daun Corynespora di Sentra Perkebunan Karet Indonesia. Jurnal Penelitian Karet, 25(1) : 76-82.

Situmorang, A., M. S. Sinaga, R. Suseno, S.H. Hidayat, Siswanto dan A. Darussamin. 2007b. Virulensi Isolat Corynespora cassiicola Asal Sentra Perkebunan Karet Indonesia terhadap Beberapa Klon Karet Anjuran. Jurnal Penelitian Karet, 25(2) : 37-58.

Sujatno, Syafiuddin dan S. Pawirosoemardjo. 1998. Resistensi Klon Harapan Terhadap Penyakit Utama Tanaman Karet. Lokakarya Nasional Pemuliaan Karet 1998 dan Diskusi Nasional Prospek Karet dalam abad 21. Pusat Penelitian Karet.: 223235.

Supriadi. 2013. Optimasi Pemanfaatan Beragam Jenis Pestisida Untuk Mengendalikan Hama dan Penyakit Tanaman. J. Litbang Pert 32(1): 1-9.

Woelan, S., Aidi-Daslin, I. Suhendry, dan M. Lasminingsih. 2005. Evaluasi Keragaan Klon Karet IRR Seri 100 dan 200. Pros. Lok. Nas. Pemuliaan Tanaman Karet. Medan, 22-23 Nopember. Balai Penelitian Sungei Putih.: 38-61.

Woelan, S., Aidi-Daslin dan I. Suhendry. 2006. Potensi Keunggulan Klon Karet Generasi IV Seri IRR. Pros. Lok. Nas. Budidaya Tanaman Karet. Medan, 4-6 September. Balai Penelitian Sungei Putih.: 33-52. 
Woelan, S dan S.A. Pasaribu. 2007. Seleksi Genotipe Hasil Persilangan 1998/1999 Berdasarkan Karakter Agronomis. Jurnal Penelitian Karet 25(2) : 10-24. 